\title{
First record of the shrew Cryptotis lacandonensis (Eulipotyphla: Soricidae) for Guatemala
}

\author{
Sergio G. Pérez ${ }^{*}$ *, Mario R. Jolón², Julio E. Mérida ${ }^{3}$ and Alexandra J. Andino-Madrid ${ }^{3}$ \\ ${ }^{1}$ Escuela de Biología, Universidad de San Carlos de Guatemala. Edificio T-10, Ciudad Universitaria zona 12, Guatemala. Guatemala, \\ Centro América. Email: sergiogperezc@gmail.com (SGP) \\ ${ }^{2}$ Rainforest Alliance, 8 avenida 15-62 zona 10, Guatemala. Guatemala, Centro América. Email: mario.jolon@gmail.com (MRJ). \\ ${ }^{3}$ Museo de Historia Natural, Escuela de Biología, al lado del Edificio J1, Ciudad Universitaria, Universidad Nacional Autónoma de \\ Honduras, Tegucigalpa. Honduras. Email:juliomerid@yahoo.com (JEM), alexandra.jahzeel@gmail.com (AJA). \\ * Corresponding author
}

A field expedition in 1995 around the community of Bethel, in the shore of the Usumacinta River, Guatemala, produced the collecting of one fluid specimen of shrew that remained unidentified as a voucher at the mammal collection at San Carlos University in Guatemala City. Our target was to identify this specimen and make the morphological comparison with a series of species of shrews of northern Central America. We extracted, cleaned the skull, and conducted a morphological comparison of the Bethel specimen with five species (20 specimens) of shrews from Guatemala and Honduras, besides the comparison with the description of C. lacandonensis Guevara, León and Woodman 2014, from Chiapas, México. We also took 13 skull measurements and conducted a morphometric analysis. Morphology of the Bethel specimen fit well with the description of $C$. lacandonensis, especially U4 upper teeth aligned with unicuspid toothrow, with a presence of a medium gap between U3-P4 that makes U4 visible in labial and lateral view. Principal component and linear discriminant analysis also showed that Bethel specimen grouped well with C. lacandonensis. Bethel shrew specimen can be identified as C. lacandonensis, the second known locality for the species and the first record for Guatemala. The community of Bethel, in Guatemala, is located only $18 \mathrm{~km}$ south of the type locality at Yaxchilán archeological site, Chiapas, México. This is a poorly known species, which merits more research.

Una expedición en 1995 en los alrededores de la comunidad de Bethel, Guatemala, a orillas del Río Usumacinta, produjo la colecta de un ejemplar de musaraña preservada en líquido, que permaneció sin identificación por varios años en la colección de mamíferos de la Universidad de San Carlos en la Ciudad de Guatemala. Nuestro objetivo fue la correcta identificación de ese ejemplar y realizar una comparación morfológica y morfométrica con otras especies de musarañas del norte de Centroamérica. Extrajimos y limpiamos el cráneo del ejemplar de Bethel y realizamos una comparación con cinco especies (20 ejemplares) de musarañas de Guatemala y Honduras, además de la comparación con lo reportado en la descripción de C. lacandonensis Guevara, León and Woodman 2014, de Chiapas, México. Tomamos 13 medidas del cráneo y realizamos un análisis morfométrico. La morfología del ejemplar de Bethel coincide con la descripción de C. lacandonensis, especialmente el diente superior U4 que se encuentran alineado con la hilera de dientes unicúspides, con presencia de una mediana separación ente U3-P4, haciendo que U4 sea visible en la vista labial y lateral. Tanto un análisis de componentes principales como el de discriminantes coincidieron en agrupar al ejemplar de Bethel con C. lacandonensis. La musaraña de Bethel puede ser identificada como un miembro de la especie C. lacandonensis, la segunda localidad conocida para la especie y el primer registro para Guatemala. La comunidad de Bethel, en Guatemala se localiza a solo 18 kilómetros al sur de la localidad tipo en el Sitio Arqueológico Yaxchilán, Chiapas, México. Esta es una especie muy poco conocida que merece más investigaciones.

Key words: Cryptotis nigrescens group; lacandona rainforest; Mayan Biosphere Reserve; morphometric analysis; Petén.

(c) 2019 Asociación Mexicana de Mastozoología, www.mastozoologiamexicana.org

\section{Introduction}

Two genera of shrews inhabit northern Central America: Sorex and Cryptotis. The small-eared short tailed shrews of the genus Cryptotis occur from southern Canada, through the United States, México and Central America, to northwestern South America (Choate 1970). There are at least 42 known species in four species-groups based on morphological and molecular characters (He et al. 2015; Hutterer 2005; Guevara et al. 2014), but their taxonomy still remains subject to many changes. Three groups and seven species are known for Guatemala: C. goodwini, C. lacertosus, C. mam, C. oreoryctes, C. tropicalis, C. mayensis, C. merriami (Hutterer 2005; Carraway 2007; Woodman 2010). The C. nigrescens group includes seven tropical and mountain species from México to the Andes, but only two are known for Guatemala: C. mayensis and C. merriami (Woodman and Timm 1993). Recently Guevara et al. (2014) described C. lacandonensis, a lowland short-tailed shrew of the $C$. nigrescens group, from the Lacandona rain forest at Yaxchilán archaelogical site, in Chiapas, México (Figure 1). C. lacandonensis is the sister species of $C$. mayensis, based on molecular information (Guevara et al. 2014, He et al. 2015), and they are the only two species known to occur in the lowlands of the Yucatan Peninsula in México, the Petén in Guatemala, and Belize. C. mayensis is widely distributed in the Yucatán Peninsula, while $C$. Iacandonensis is currently known only from the type locality, on the eastern and Mexican shore of the Usumacinta River. This is the longest and largest river of northern Central America, and the portion that serves as the border line between México and Guatemala has a very rainy climate, which differs from the common dryer areas of the Yucatán Peninsula.

The revision of an unidentified specimen of shrew deposited at the mammal collection of San Carlos University in Guatemala City put us the task of identifying it. The 


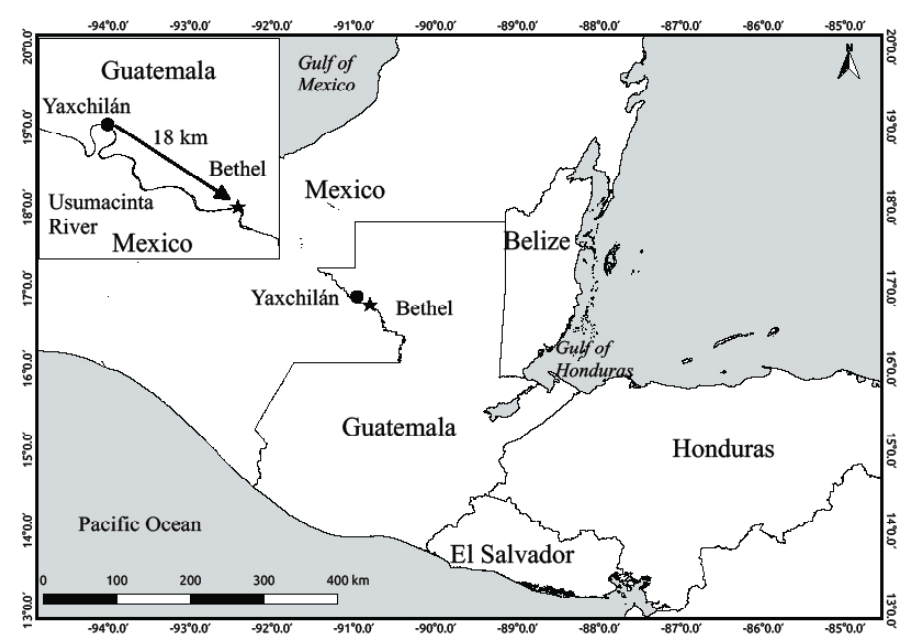

Figure 1. Map of Guatemala and adjacent areas showing the locality at the Community of Bethel, Petén, Guatemala, where "Bethel specimen" was collected, and the type locality of Cryptotis lacandonensis at Yaxchilán Archeological site in nearby Chiapas, México (taken from Guevara et al. 2014)

specimen comes from the area of the Usumacinta River on the side of Guatemala, at the community of Bethel, Petén. With that purpose we conducted comparisons with a series of shrews from the lowland and highlands of nearby areas, both morphological and morphometrically, with the main target of resolving this identification problem.

\section{Material and methods}

On November 19, 1995 one of us (MRJ) collected one specimen of shrew while conducting a small mammal inventory research around the community of Bethel, $74 \mathrm{~km}$ W La Libertad, Department of Petén, Guatemala, $130 \mathrm{~m}$, ca. $16.8267^{\circ} \mathrm{N},-90.8122^{\circ} \mathrm{W}$ (Figure 1). The specimen is an adult female captured with a Sherman trap (field number

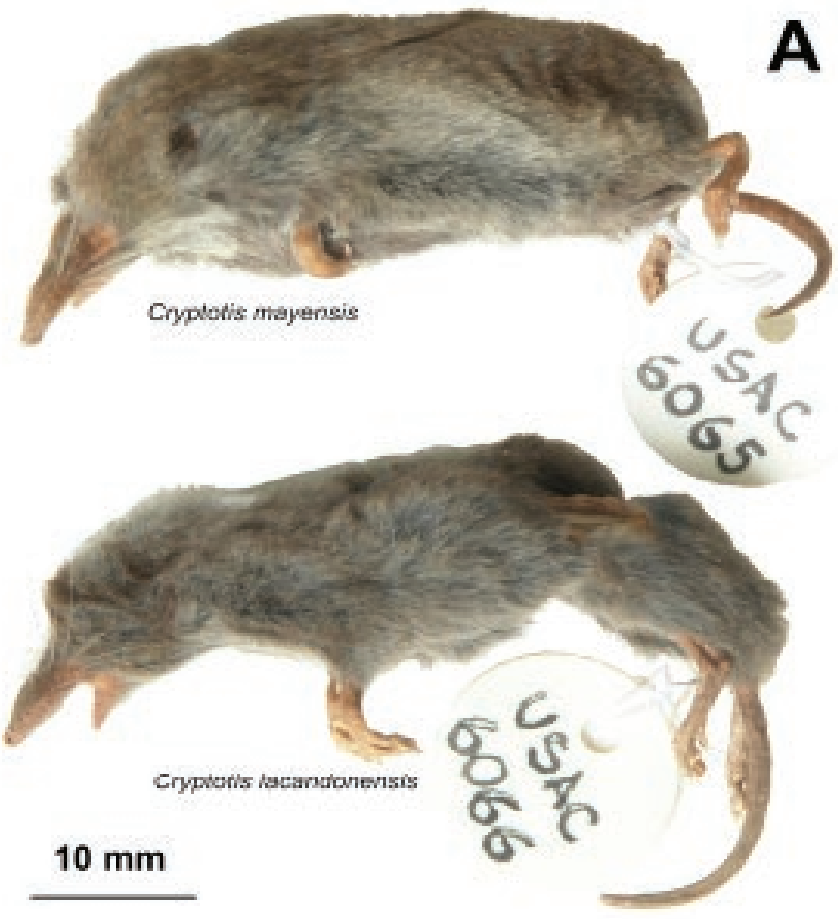

MRJ 103), preserved in fluid-alcohol, and deposited at the mammal collection at Universidad de San Carlos de Guatemala (USAC 6066, Figure 2), without any identification to the species level. We will refer to this specimen later on as the "Bethel specimen".

The area of Bethel is located at the southernmost limit of the Sierra del Lacandón National Park, which is also part of the Mayan Biosphere Reserve. The area was at that time covered mainly by humid tropical forest and seasonally flooded areas, but crops and cattle now dominate it. Nonetheless, pristine forest is still found in nearby wild protected areas both in México and in Guatemala (Méndez 1997). The original forest is classified as "high evergreen jungle" based on Miranda and Hernandez-X classification (Challenger and Soberón 2008), with different habitats locally known as "planicies" (tall forests on non-inundated plains), "bajos" (swamps with short forest), and "serranías" (tall forest on hills). Common species of trees in the area include: Brosimum alicastrum Sw. 1788, Brosimun costaricanum Liebm. 1851, Pouteria reticulata (Engl.) Eyma 1936, Alseis yucatanensis Standl. 1930, Coccoloba barbadensis Jacq. 1760, Blomia prisca (Standl.) Lundell 1961, Terminalia amazonia (J. F. Gmel.) Exell 1935, Coccoloba barbadensis Jacq. 1760, Simaruba amara Aubl. 1775, Calophyllum brasiliense Cambess. (1828) among others (Méndez 1997; Soto 2003).

With the target of correctly identify this specimen, we recently extracted the skull of this fluid preserved specimen and then cleaned it with the help of a dermestid beetles' culture, and then with a soft solution of ammoniac. For comparative reasons, we also examined 20 additional skulls within the $C$. nigrescens group (C. merriami and C. mayensis), C. goldmani group (C. mam and C. goodwini), and C. parva

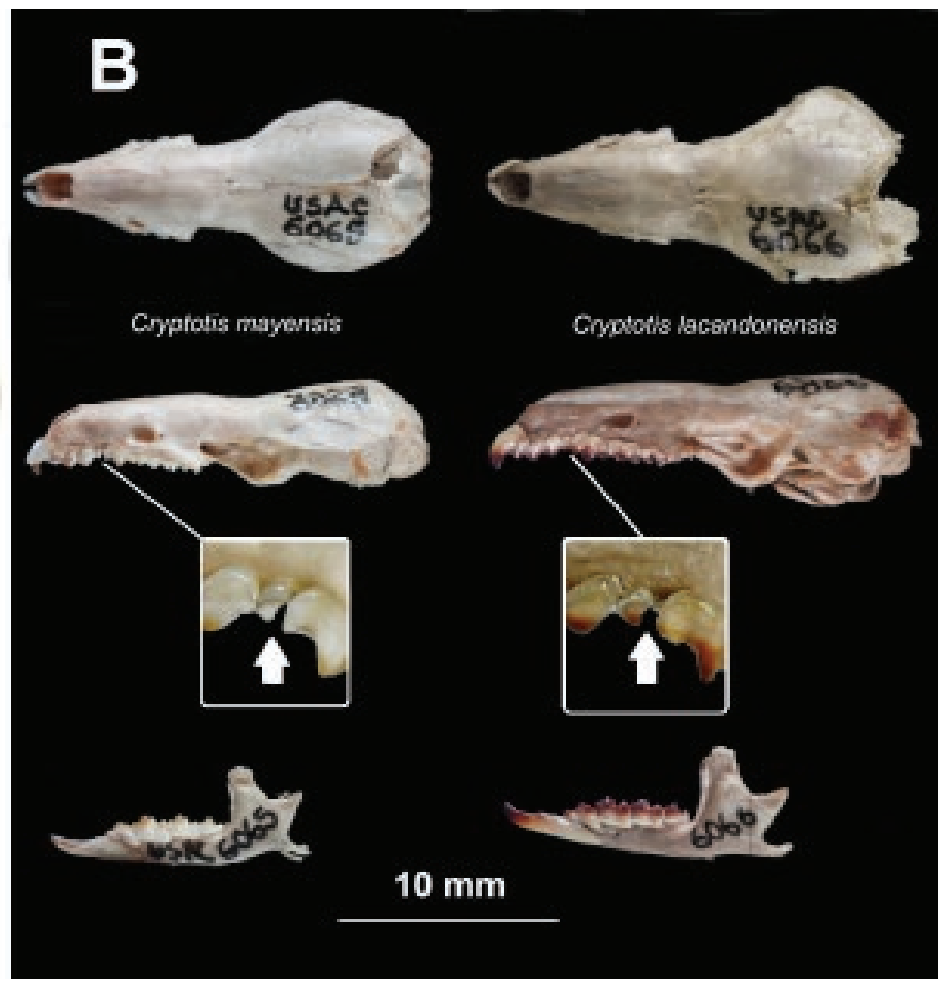

Figure 2. A: fluid preserved specimens of Cryptotis lacandonensis USAC6066 (down) and C. mayensis USAC6065 (up). B: skulls of Cryptotis lacandonensis (right) and C. mayensis (left) in dorsal, lateral, and lateral mandibles (down); inserted are magnifications of labial views of the upper fourth unicuspid teeth (U4). 
group (C. tropicalis). These specimens are deposited in two collections: Universidad de San Carlos de Guatemala (USAC) and Museo de Historia Natural, Ciudad Universitaria, Universidad Nacional Autónoma de Honduras (UNAH-CU); a complete list of specimens examined and their localities is given in the forward section. We were not able to check directly the holotype and paratype of $C$. lacandonensis, as it is desired in this comparisons, but since it was one of the probable names for the Bethel specimen, due to the proximity to the type locality, we included in the morphometric analysis the measurements of the holotype and paratype reported in Guevara et al. (2014).

We obtained 13 cranial measurements of all skulls following Woodman and Timm 1993: condylobasal length, not including the upper incisors (CBL); cranial breadth (CB); breadth of zygomatic plate (ZP); interorbital breadth (IO); breadth of palate across first unicuspids (U1B); breadth of palate across third unicuspids (U3B); breadth of palate across second molars (M2B); palatal length (PL); upper tooth row length, UI to M3 (TR); molariform tooth row length, P4 to M3 (MTR); height of coronoid process (HCP); height of coronoid valley (HCV); lower tooth row length, length $\mathrm{p} 3$ to $\mathrm{m} 3$ (TRD). All measurements were recorded in millimeters to the nearest $0.1 \mathrm{~mm}$ using an electronic caliper TRUPER ${ }^{\circledR}$. For the majority of specimens examined, and when available, we took note of standard external measurements recorded by the collectors in the field, with the majority written in their museum tags or recorded in collections data bases: total length (TL), length of tail (LT), and hind foot (HF), in millimeters. Sex of specimens was that recorded on tags or by field notes, or when possible, determined in the laboratory following Searle (1985).

We conducted a Principal Component Analysis (PCA) and a Linear Discriminant Analysis (LDA) with craniodental measurements, to see if the Bethel specimen groups with any of the known shrew specimens of the area. We used transformed Log10 measurements to reduce the excessive weight of some of the variables (Sokal and Rohlf, 2012). External measurements were not included in the morphometric analysis. Because of the limited number of specimens examined and to avoid saturation of the analysis, we explored pair correlations of variables (results not shown) and avoided to use the most redundancy ones. We decided to use only eight selected variables for PCA and LDA analysis. We also confirmed normality of all variables. Both PCA and LDA included 23 individuals in total (Bethel specimen plus 20 specimens examined and two type specimens reported in Guevara et al. (2014).

All calculations were performed in $\mathrm{R}$ version 3.4.1 ( $\mathrm{R}$ Development Core Team 2017). PCA was finally performed with 23 individuals and eight selected variables $(C B L, C B$, $Z P, M 2 B, M T R, T R$, and TRD), using the package FactoMineR (Lê et al. 2008). We then evaluated the conformation of the groups (species) a priori considered in this study through a Linear Discriminant Analysis (LDA) with the same eight variables and to be able to evaluate the Bethel specimen as part of $C$. lacandonensis; this was done with the package MASS (Venables and Ripley 2002). We then plotted the first two components of PCA and LDA with ggplot2 (Wickham 2016).

Specimens examined:

Bethel specimen (Cryptotis cf. lacandonensis): GUATEMALA: Comunidad Bethel. Las Cruces, Petén, $122 \mathrm{~m}, 16.8219^{\circ} \mathrm{N}$, -90.8036 W (1F, USAC6066).

C. mayensis: GUATEMALA: Sylvanus Morley Museum, Tikal National Park, Flores, Petén, $246 \mathrm{~m}, 17.2257^{\circ} \mathrm{N}$, $-89.6126^{\circ} \mathrm{W}(1 \mathrm{~F}, \mathrm{USAC6065)}$.

C. merriami. HONDURAS: Parque Nacional La Tigra, Francisco Morazán $14.8506^{\circ} \mathrm{N},-87.5201^{\circ} \mathrm{W}$ (MHN-CU 20160020, MHN-CU 20150015). GUATEMALA: Aldea El Duraznal, Trifinio National Park, $1.6 \mathrm{~km} \mathrm{S,} 7 \mathrm{~km}$ E Concepción Las Minas, Chiquimula, 1,655 m, $14.5063^{\circ} \mathrm{N},-89.3804^{\circ} \mathrm{W}(1 \mathrm{M}$, USAC5864); Finca Biotopin, 2.3 km S, 1.6 km E Purulhá, Baja Verapaz, $1,705 \mathrm{~m}, 15.2168333^{\circ} \mathrm{N}, 90.2181389^{\circ} \mathrm{W}$ (1 sex undetermined, USAC 5866).

C. goodwini: GUATEMALA: Finca Barillas, $11.5 \mathrm{Km} \mathrm{N}$, 1.1 Km W Colomba Costa Cuca, Quetzaltenango, 1,680 $\mathrm{m}, 14.8130^{\circ} \mathrm{N},-91.7405^{\circ} \mathrm{W}$ (2F, USAC5661, USAC5680); Volcán Acatenango, ca. $1.6 \mathrm{~km} \mathrm{~S}, 6.4 \mathrm{~km} \mathrm{E}$ Acatenango, Chimaltenango, 3,000 m, $14.5211^{\circ} \mathrm{N},-90.8797^{\circ} \mathrm{W}(1 \mathrm{~F}$, USAC1037); Parque Ecológico Cayalá, zona 16, Ciudad de Guatemala, Guatemala, 1,451 m, $14.6199^{\circ} \mathrm{N},-90.4893^{\circ} \mathrm{W}$ (2M, USAC1021, USAC0059); Finca El Pilar, Magdalena Milpas Altas, 11 km SE Antigua Guatemala, Sacatepéquez, 2,640 m, 14.5180 N, -90.6919 (1M, USAC5870); Cumbre de Montecristo, Esquipulas, Chiquimula, $2,400 \mathrm{~m} 14.4192^{\circ} \mathrm{N}$, -89.3558, (3F, USAC3325, USAC3319, USAC3334)); Las Minas, Los Planes, Chiquimula, (1, sex undetermined, USAC2384).

C. mam: GUATEMALA: San Francisco, El Retiro, Cuilco, Huehuetenango, 2,975m. $15.4854^{\circ} \mathrm{N},-91.9327^{\circ} \mathrm{W}(1 \mathrm{~F}$ USAC5748).

C. tropicalis: GUATEMALA: Cerro el Gigante, $5.3 \mathrm{~km} \mathrm{~N}$, 13.4 Km W Chiquimula $1745 \mathrm{~m}, 14.8458^{\circ} \mathrm{N},-89.6667^{\circ} \mathrm{W}$ (2M USAC5426, USAC5443); Parque Ecológico Cayalá, zona 16, Ciudad de Guatemala, Guatemala, 1451 m, 14.6199 $\mathrm{N}$, $90.4893^{\circ} \mathrm{W}$ ( 2 sex undetermined, USAC1020, USAC 1019).

\section{Results}

A morphological comparison of skulls showed that the Bethel specimen (USAC 6066) is similar to specimens of C. merriami from the mountains southward in Guatemala, but they are differentiated by the general bigger size of $C$. merriami, which also has a bigger maxillary U4 tooth and much wider gap between U3 and P4, giving more room to U4. In comparison with C. mayensis (USAC 6065), the Bethel specimen is bigger, and also can be differentiated by the presence of a medium size U3-P4 gap (but not as wide as in C. merriami), which is wide enough to let medium tooth U4 partially visible in labial view of the skull (see Figure 2B, magnification inserted, see arrow); in C. mayensis, U3 and P4 appear almost in touch, with a small and intermediate U4 hidden in lateral view (Figure 2B). Externally, both $C$. 
mayensis and Bethel specimen show a general dark grayish pattern, but C. mayensis from Tikal is slightly more brownish in the dorsal pelage (Fig. 2A).

External and cranial measurements of the Bethel female specimen (USAC 6066) are as follows [incomplete or esti- mated measurements in brackets]: TL 92, LT 27, HF 12; CBL [18.40], CB 8.80, ZP 2.44, IO 4.48, U1B 2.16, U3B 2.68, M2B 5.19, PL 8.35, TR 7.22, MTR 5.26, HCP 5.39, HCV 3.03, TRD 5.61. Measurements of this and all other specimens included in the analysis are shown in Table 1.

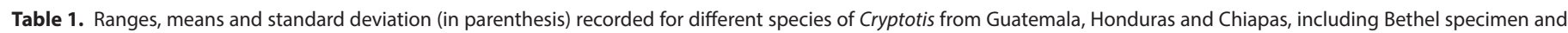
reported measurements of type specimens of C. lacandonensis taken from Guevara et al. (2014). Abbreviations of variables follow those described in text.

\begin{tabular}{|c|c|c|c|c|c|c|c|}
\hline & C. goldmani & & C. parva group & & C. nigr & ens group & \\
\hline Variables & $\begin{array}{c}\text { C. goodwini } \\
(n=10, \text { except external } \\
\text { measurements })\end{array}$ & $\begin{array}{l}\text { C. mam } \\
(n=1)\end{array}$ & $\begin{array}{c}\text { C. tropicalis } \\
\text { ( } n=4 \text { except external } \\
\text { measurements })\end{array}$ & $\begin{array}{c}\text { C. merriami } \\
\text { ( } n=4 \text {, except external } \\
\text { measurements })\end{array}$ & $\begin{array}{l}\text { C. mayensis } \\
(n=1)\end{array}$ & $\begin{array}{l}\text { Bethel specimen } \\
\qquad(n=1)\end{array}$ & $\begin{array}{l}\text { C. lacandonensis (from } \\
\text { Guevara et al. 2014, } \\
\qquad n=2 \text { ) }\end{array}$ \\
\hline $\mathrm{HB}$ & $\begin{array}{c}70.00-96.00 \\
84.28 \\
(9.21) \\
(n=7)\end{array}$ & 82 & $\begin{array}{l}54,59 \\
(n=2)\end{array}$ & $\begin{array}{l}78,83 \\
(n=2)\end{array}$ & $\begin{array}{c}57 \\
\text { (from fluid } \\
\text { specimen) }\end{array}$ & $\begin{array}{c}65 \\
\text { (from fluid } \\
\text { specimen) }\end{array}$ & 78,81 \\
\hline LT & $\begin{array}{c}26.00-31.00 \\
29.00 \\
(2.00) \\
(n=7)\end{array}$ & 29 & $\begin{array}{l}22,22 \\
(n=2)\end{array}$ & $\begin{array}{l}24,32 \\
(n=2)\end{array}$ & $\begin{array}{c}23 \\
\text { (from fluid } \\
\text { specimen) }\end{array}$ & $\begin{array}{c}27 \\
\text { (from fluid } \\
\text { specimen) }\end{array}$ & 33,35 \\
\hline $\mathrm{HF}$ & $\begin{array}{c}13.00-15.00 \\
14.14 \\
(0.89) \\
(n=7)\end{array}$ & 15 & $\begin{array}{l}11,11 \\
(n=2)\end{array}$ & $\begin{array}{l}11,13 \\
(n=2)\end{array}$ & $\begin{array}{c}10 \\
\text { (from fluid } \\
\text { specimen) }\end{array}$ & $\begin{array}{c}12 \\
\text { (from fluid } \\
\text { specimen) }\end{array}$ & -- \\
\hline $\mathrm{CBL}$ & $\begin{array}{c}19.98-21.52 \\
20.79 \\
(0.59)\end{array}$ & 21.45 & $\begin{array}{c}16.49-17.51 \\
16.94 \\
(0.42)\end{array}$ & $\begin{array}{c}18.5-19.73 \\
18.94 \\
(0.56)\end{array}$ & 17.58 & 18.4 & $20.1,20.5$ \\
\hline $\mathrm{CB}$ & $\begin{array}{c}10.42-11.13 \\
10.75 \\
(0.22)\end{array}$ & 9.87 & $\begin{array}{c}7.64-8.85 \\
8.25 \\
(0.60)\end{array}$ & $\begin{array}{c}9.20-9.71 \\
9.43 \\
(0.26)\end{array}$ & 8.17 & 8.8 & $9.6,9.7$ \\
\hline 10 & $\begin{array}{c}5.3-5.84 \\
5.47 \\
0.17\end{array}$ & 5.5 & $\begin{array}{c}3.94-4.33 \\
4.12 \\
(0.17)\end{array}$ & $\begin{array}{c}4.55-4.86 \\
4.64 \\
(0.14)\end{array}$ & 3.9 & 4.48 & $4.7,4.8$ \\
\hline ZP & $\begin{array}{c}1.87-2.39 \\
2.12 \\
(0.16)\end{array}$ & 2.53 & $\begin{array}{c}1.44-1.91 \\
1.69 \\
(0.22)\end{array}$ & $\begin{array}{c}2.07-2.31 \\
2.21 \\
(0.11)\end{array}$ & 2.31 & 2.44 & $2.7,2.4$ \\
\hline $\mathrm{PL}$ & $\begin{array}{c}8.49-9.24 \\
8.83 \\
(0.30)\end{array}$ & 8.85 & $\begin{array}{c}6.47-7.28 \\
6.82 \\
(0.39)\end{array}$ & $\begin{array}{c}7.75-8.50 \\
8.09 \\
(0.39)\end{array}$ & 7.67 & 8.35 & $9.1,9.1$ \\
\hline $\mathrm{M} 2 \mathrm{~B}$ & $\begin{array}{c}5.81-6.24 \\
6.08 \\
(0.12)\end{array}$ & 6.08 & $\begin{array}{c}5-5.37 \\
5.18 \\
(0.17)\end{array}$ & $\begin{array}{c}5.41-4.45 \\
5.43 \\
(0.01)\end{array}$ & 4.89 & 5.19 & $5.5,5.4$ \\
\hline U1B & $\begin{array}{c}2.55-3.18 \\
2.69 \\
(0.18)\end{array}$ & 2,61 & $\begin{array}{c}2.01-2.40 \\
2.21 \\
(0.19)\end{array}$ & $\begin{array}{c}2.19-2.41 \\
2.44 \\
(0.23)\end{array}$ & 2.15 & 2.16 & $2.6,2.6$ \\
\hline U3B & $\begin{array}{c}3.07-3.41 \\
3.23 \\
(0.11)\end{array}$ & 3.05 & $\begin{array}{c}2.53-2.78 \\
2.7 \\
(0.11)\end{array}$ & $\begin{array}{c}2.70-3.17 \\
2.95 \\
(0.19)\end{array}$ & 2.42 & 2.68 & $3.1,3.0$ \\
\hline MTR & $\begin{array}{c}5.23-5.78 \\
5.5 \\
(0.17)\end{array}$ & 5.46 & $\begin{array}{c}4.18-4.56 \\
4.34 \\
(0.18)\end{array}$ & $\begin{array}{c}4.99-5.49 \\
5.18 \\
(0.22)\end{array}$ & 4.88 & 5.26 & $5.3,5.2$ \\
\hline TR & $\begin{array}{c}7.44-7.98 \\
7.69 \\
(0.19)\end{array}$ & 7.91 & $\begin{array}{c}6-6.28 \\
6.1 \\
(0.13)\end{array}$ & $\begin{array}{c}7.12-7.76 \\
7.37 \\
(0.29)\end{array}$ & 6.51 & 7.22 & $7.7,7.7$ \\
\hline TRD & $\begin{array}{c}5.94-6.5 \\
6.26 \\
(0.20)\end{array}$ & 6.47 & $\begin{array}{c}4.75-5.05 \\
4.91 \\
(0.14)\end{array}$ & $\begin{array}{c}5.35-5.80 \\
5.57 \\
(0.18)\end{array}$ & 5.42 & 5.61 & $5.6,5.8$ \\
\hline $\mathrm{HCP}$ & $\begin{array}{c}4.64-5.19 \\
4.83 \\
0.16\end{array}$ & 4.78 & $\begin{array}{c}4.01-4.27 \\
4.14 \\
(0.11)\end{array}$ & $\begin{array}{c}4.51-4.97 \\
4.73 \\
(0.18)\end{array}$ & 4.41 & 5.39 & $5.0,5.2$ \\
\hline $\mathrm{HCV}$ & $\begin{array}{c}2.87-3.4 \\
3.07 \\
(0.17)\end{array}$ & 3.12 & $\begin{array}{c}2.37-2.63 \\
2.48 \\
(0.13)\end{array}$ & $\begin{array}{c}2.65-2.99 \\
2.80 \\
(0.16)\end{array}$ & 2.5 & 3.03 & $2.8,2.7$ \\
\hline
\end{tabular}




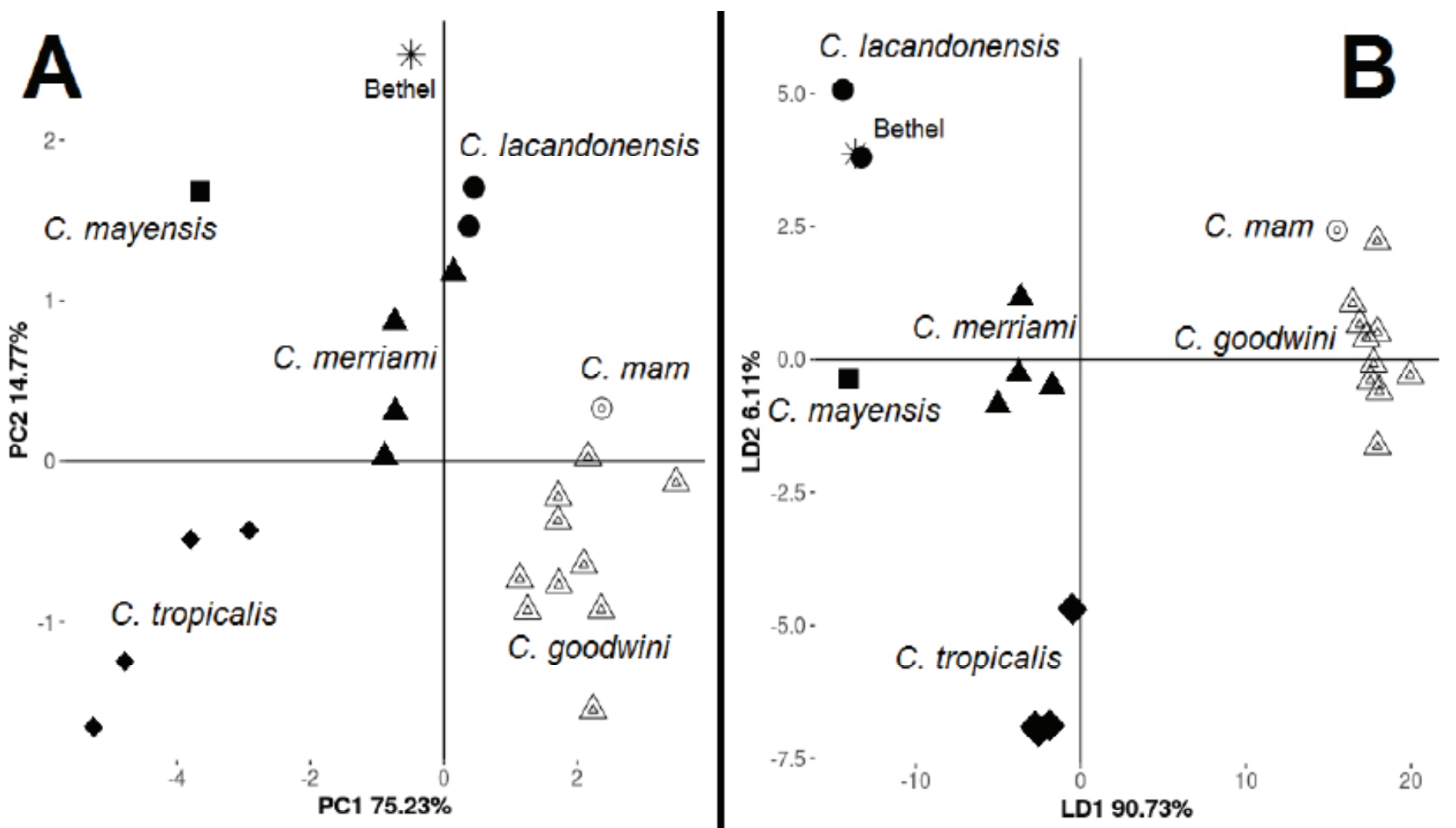

Figure 3. Scatter plot of principal component analysis (A) and linear discriminant analysis (B) for different species of Cryptotis from Chiapas, Guatemala and Honduras. Bethel specimen is marked with an asterisk.

External measurements of the Bethel specimen are smaller from those reported for the types of C. lacandonensis in Guevara et al. (2014), but much bigger in comparison with the specimen of $C$. mayensis (USAC 6065) measured with the same method (see Figure 2A). Skull measurements are similar (but slightly smaller) from those reported for $C$. lacandonensis; and in comparison with C. mayensis they are generally bigger.

Principal component analysis (Figure $3 \mathrm{~A}$ ) showed that the first two axes explains $90 \%$ of the variation (PC1 75.23 $\%$, PC2 $14.77 \%$ ). The measures CBL, TRD and IO were the ones with the highest scores and contributions to PC1, meanwhile ZP and HCP were the ones with the highest contributions to PC2 (see factor loadings shown in Table 2). The PCA showed that bigger size and highland species of the $C$. goldmani group (C. goodwini and C. mam) were located at the bottom-right side of the graphic, and smaller lowland species of the $C$. nigrescens group ( $C$. merriami, $C$. mayensis,

Table 2. Factor loadings from PCA and LDA for axes 1 and 2

\begin{tabular}{lcccr}
\hline \multicolumn{1}{c}{ Variables } & PCA & & \multicolumn{2}{c}{ LDA } \\
& PC1 & PC2 & LD1 & LD2 \\
\hline CBL & $\mathbf{0 . 3 9 3 1}$ & -0.0424 & -0.3657 & 0.2382 \\
TRD & $\mathbf{0 . 3 8 7 3}$ & -0.0168 & $\mathbf{0 . 5 2 7 5}$ & 0.0338 \\
IO & $\mathbf{0 . 3 8 3 6}$ & -0.2729 & 0.2515 & 0.4516 \\
M2B & 0.3705 & -0.3442 & 0.1851 & $\mathbf{- 0 . 6 3 8 1}$ \\
HCV & 0.3702 & 0.0552 & 0.3595 & -0.2133 \\
U3B & 0.3513 & -0.2308 & 0.0947 & -0.0838 \\
HCP & 0.3140 & $\mathbf{0 . 4 8 7 7}$ & $-\mathbf{0 . 5 7 2 9}$ & $\mathbf{0 . 4 7 3 0}$ \\
ZP & 0.2279 & $\mathbf{0 . 7 1 4 7}$ & -0.1555 & 0.2342 \\
\hline
\end{tabular}

and C. lacandonensis) and parva group (C. tropicalis) were placed on the left side of the graphic (Figure 3A). Bethel specimen (showed only as "Bethel") appeared close but not well grouped with $C$. lacandonensis.

LDA results (Figure $3 \mathrm{~B}$ ) are in general in accordance with PCA, with highland species (C. goodwini and C. mam) at the right side of the graph, and lowland species well discriminated at the bottom ( $C$. tropicalis), center left (C. merriami and C. mayensis), and top-left (C. lacandonensis and Bethel specimen). In general, LDA was better to discriminate species and groups than PCA, placing the Bethel specimen decidedly closer to C. lacandonensis than to C. mayensis. In LDA, the first function explains $90.73 \%$ of the variance, with higher weights for HCP and TRD (see Table 2 for factor loadings), while the second function explains the $6.11 \%$ of the variance with higher weights for $\mathrm{M} 2 \mathrm{~B}$ and $\mathrm{HCP}$. LDA showed the conformation of well-defined groups, represented by the a priori species designations, and the classification function was $100 \%$ in accordance with these designations.

\section{Discussion and Conclusion}

Habitat of the community of Bethel is practically the same to that of the type locality at Yaxchilán, Chiapas, México. The majority of species of the genus Cryptotis inhabit the mountains of southern Nuclear Central America, with only two species occurring in the lowlands of the Yucatán Península, C. lacandonensis and C. mayensis. Nonetheless, C. mayensis appears to be restricted to dryer and northernmost areas of the peninsula (Cuarón et al. 2016), with no overlapping distribution with C. lacandonensis. The forest at Tikal, 
for example, is classified as "high sub-evergreen jungle" (Challenger and Soberón 2008), with more seasonality during the long dry seasons, and with very little surface water run-off. The vegetation at Tikal is similar to Bethel, but is more dominated by Brosimum, Swietenia, Cedrella and other dry forest species (Schulze and Whitacre 1999; Jolón 1996). So the distribution of $C$. lacandonensis was expected to extend around the neighbor humid lowlands areas of the type locality at the Usumacinta River (Guevara et al. 2014).

Because of the general morphology, teeth pattern, coloration, and results of the PCA and LDA analysis, we conclude that Bethel specimen can be determined as Cryptotis lacandonensis. Nonetheless, not all information fit perfectly with the description of the species, because the external measurements are smaller from those of the type locality, although we are aware of the potential differences that may be due to many factors. These factors include the way the measurements were taken, for example if taken in the field or from preserved specimens, and also differences due to sex, age or regional variations that we simply do not know about.

The Bethel specimen represents a small range distributional extension for the species, but the first record for Guatemala. C. lacandonensis remains as an endemic species to the lowlands of the Usumacinta River basin, with potential as species flag for conservation porpoises on both sides of the Mexican-Guatemalan border. Life history and ecology is mostly unknown, and research on these aspects is still needed. Due to its known restricted distributional extension and the rapidly fragmentation of the original forest (mainly in Guatemala), this small mammal is a good candidate to be considered in threat, but its classification as "data deficient" is good for now.

The evolutionary history of the $C$. nigrescens group in Nuclear Central America still needs to be untangled. We do not know how and when the divergence of $C$. merriami, $C$. mayensis and $C$. lacandonensis occurred. The first species is relatively common at mid elevations at the southern side of Nuclear Central America, and shows a complex variation that in the future could be clue to resolve many of the present doubts.

At present, the area of the Usumacinta River, especially on the side of Guatemala, is suffering a drastic forest loss and increase of human population. We do not know if this species will be able to adapt and survive to this new scenario. Fortunately, there are important efforts of conservation of nature being held on both sides of the border in México and Guatemala and we hope that this rare species gets more attention.

\section{Acknowledgements}

Field collecting permits were granted by Consejo Nacional de Areas Protegidas (CONAP), Guatemala. We are very grateful with C. Méndez from the School of Biology at USAC, and C. Galindo-Leal from CCB Stanford University, for providing field facilities and assistance during 1994-1997. L.
Meléndez assisted with the picture work. This manuscript is part of the project "Biotic inventories and evolution of the terrestrial vertebrate fauna of Nuclear Central America", NSF grant DEB1026393 to R. Bowie. We dedicate this paper to Gustavo A. Cruz (MHN-UNAH, Honduras), for his valuable contributions to the knowledge of the Central American vertebrate fauna.

\section{Literature cited}

Carraway, L. N. 2007. Shrews (Eulypotyphla: Soricidae) of México. Monographs of the Western North American Naturalist 3:1-91.

Challenger, A., AND J. Soberón. 2008. Los ecosistemas terrestres. Pp. 87-108 in Capital natural de México, vol. I, Conocimiento actual de la biodiversidad (Sarukhan, J., ed.). Comisión Nacional para el Conocimiento y Uso de la Biodiversidad. Ciudad de México, México.

CHOATE, J. R. 1970. Systematics and zoogeography of Middle American shrews of the genus Cryptotis. University of Kansas Publications, Museum of Natural History 19:195-317.

Cuarón, A. D., P. C. de Grammont, N. Woodman, and J. Matson. 2016. Cryptotis mayensis. The IUCN Red List of Threatened Species 2016: e.T136488A22284758. http://dx.doi.org/10.2305/IUCN. UK.2016-2.RLTS.T136488A22284758.en. Downloaded on 07 March 2019

Guevara, L., V. Sánchez-Cordero, L. León-Paniagua, and N. Woodman. 2014. A new species of small-eared shrew (Mammalia, Eulipotyphla, Cryptotis), from the Lacandona rain forest, Mexico. Journal of Mammalogy 95: 739-753.

He, K., N. Woodman, S. Boaglio, M. Roberts, S. Supekar, and J. MALDONADO. 2015. Molecular phylogeny supports repeated adaptation to burrowing within small-eared shrews genus of Cryptotis (Eulipotyphla, Soricidae). PloS One 10: e0140280. https://doi.org/10.1371/journal.pone.0140280

HuttereR, R. 2005. Order Soricomorpha. Pp. 220-311 in Mammal's species of the world, a taxonomic and geographic reference, third edition, Vol. I (Wilson, D. E., ed.). The Johns Hopkins University Press. Baltimore, U. S. A.

JoLón M. R. 1996. Ecología poblacional del ratón espinoso de bolsas Heteromys desmarestianus (Rodentia: Heteromyidae) en el Parque Nacional Tikal, Petén, Guatemala. Undergraduate dissertation. Facultad de Ciencias Químicas y Farmacia, Universidad de San Carlos de Guatemala. Guatemala, Guatemala.

LEE, S., JossE, J., AND F. Husson. 2008. FactoMineR: An R Package for Multivariate Analysis. Journal of Statistical Software 25:1-18.

Méndez, C. A. 1997. Diseño de un programa de monitoreo biológico a largo plazo mostrado a través de un estudio de caso: el corte selectivo del bosque en la Cooperativa Bethel, La Libertad, Petén. Undergraduate dissertation. Facultad de Ciencias Químicas y Farmacia, Universidad de San Carlos de Guatemala, Guatemala.

R Development Core Team. 2017. R: A language and environment for statistical computing. R Foundation for Statistical Computing, Vienna, Austria 2009 [http://www.R-project.org]. Schulze, M. D., AND D. F. Whitacre. 1999. A classification and ordination of the tree community of Tikal National Park, Petén, Guatemala. Bulletin of the Florida Museum of Natural History 41:169-297. 
SeArLe, J. B. 1985. Methods for determining the sex of Common shrews (Sorex araneus). Journal of Zoology 206:279-282.

SOKAL, R. R.. AND F. J. RoHLF. 2012. Biometry Fourth Edition. W. H. Freeman Company. New York, U. S. A.

Sото, J. R. 2003. Impactos de cacería de una comunidad del Parque Nacional Sierra del Lacandón, La Libertad, Petén sobre vertebrados mayores y terrestres y arbóreos. Undergraduate dissertation. Universidad de San Carlos de Guatemala. Available at: http://biblioteca.usac.edu.gt/tesis/06/06_2175.pdf.

Venables, W. N., AND B. D. Ripley. 2002. Modern Applied Statistics with S. Fourth Edition. Springer, New York, U. S. A.

WiCKHAM, H. 2016. ggplot2: Elegant Graphics for Data Analysis. Springer-Verlag New York, U. S. A.

Woodman, N. 2010. Two new species of shrews (Soricidae) from the western highlands of Guatemala. Journal of Mammalogy 91:566-579

WoOdMAN, N., AND R. M. TIMm. 1993. Intraspecific and interspecific variation in the Cryptotis nigrescens species complex of smalleared shrews (Insectivora: Soricidae), with description of a new species from Colombia. Fieldiana Zoology (n. s.) 74:1-30.

Associated editor: Lázaro Guevara.

Submitted: January 21, 2019; Reviewed: February 11, 2019;

Accepted: April 3, 2019; Published on line: May 2, 2019. 
194 THERYA Vol. 10 (2): 187-193 